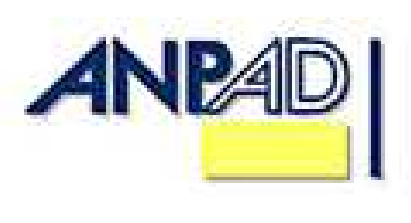

Available online at http://www.anpad.org.br/bar

BAR, Rio de Janeiro, v. 10, n. 1, art. 4, pp. 57-76, Jan./Mar. 2013

\title{
An Examination of Human Resource Management Practices' Influence on Organizational Commitment and Entrenchment
}

\author{
Alba Couto Falcão Scheible * \\ E-mail address: ac.scheible@globo.com \\ Universidade Federal da Bahia - NPGA/UFBA \\ Salvador, BA, Brazil. \\ Antônio Virgílio Bittencourt Bastos \\ E-mail address: virgilio@ufba.br \\ Universidade Federal da Bahia - NPGA/UFBA \\ Salvador, BA, Brazil.
}

* Corresponding author: Alba Couto Falcão Scheible

R. Clara Nunes, 310, apto. 102, Caminho das Árvores, Salvador, BA, 41810-425, Brazil.

Received 15 July 2011; received in revised form 17 July 2012 (this paper has been with the authors for two revisions); accepted 13 August 2012; published online 27 November 2012. 


\begin{abstract}
This study sought to understand how the employee perceptions of human resource management practices influence both organizational affective commitment and entrenchment. It represents advancement towards discriminant validity of such linkages that develop between individuals and the organizations they work for. A survey of 307 participants was conducted in an Information Technology company in Brazil. It was found that affective commitment has a strong and positive relationship with perceptions of HRM practices, while entrenchment is also related, but in a very weak fashion. Training and development practices showed better fit with the expected results of such practices in the organization studied, strongly affecting commitment, but not enhancing entrenchment. Even if not generalizable, these results strengthen the research stream that defends that commitment and entrenchment are separate constructs.
\end{abstract}

Key words: commitment; entrenchment; HRM practices. 


\section{Introduction}

Globalization and the pressure for innovation as means of survival have changed the psychological contract between organizations and their employees. Guarantee of employment can no longer be used to generate commitment (Meyer, Allen, \& Topolnytsky, 1998). As a result, workers today do not expect to develop their careers in only one organization (Nussbaum, 1991 as cited in Carson \& Bedeian, 1994). Cooper-Hakim and Viswesvaran (2005) estimate an average of five changes of organization throughout a career. Since it is no longer possible to secure jobs, companies attempt to ensure employability and, to that end, invest in developing their people to enhance their potential mobility. This ultimately generates a paradox because companies must also retain the talents they need. Thus, there is now a demand for managerial strategies appropriate for this scenario in order to retain good employees through practices such as awards, promotions, compensation, and training (Buckingham \& Coffman, 1999 as cited in Barros, 2007).

It is important for organizations to foster linkages for people to remain, but it is also important to assess the nature of these bonds. Affective bonds are those that engender stronger ties since they are associated with an organization's goals and values. On the other hand, bonds based on instrumental exchanges might make it less attractive for people to leave the organization since they would be losing investments and gains already obtained (McElroy, 2001a; Morrow, 2011; Sethi \& King, 2008; Steel \& Lounsbury, 2009).

Although several studies point out the importance of commitment to organizational outcomes (Pfeffer, 1998; Riketta, 2002; Steel \& Lounsbury, 2009), many issues still pose challenges for managers. A possible answer to these issues could be planned management of commitments. Kiesler (1971) explains that commitment has motivational factors, and even though it might not be a sufficient enough factor to compel action, it ultimately influences the way individuals react to situations, due to its binding properties. So, it can end up driving behaviors. However, can commitments be deliberately and purposefully managed? According to Meyer and Allen (1997, p. 69), this is possible because commitment "is actually related to employees' perception regarding Human Resource Management (HRM) practices". Morrow (2011) adds that the answer to this question lies in identifying factors that affect commitments. Among them, which practices are appropriate for generating commitment and its presumed impact on other linkages?

Sethi and King (1998) studied organizational commitment in Information Technology (IT) professionals and suggest that organizations should carefully examine their policies related to enhancing commitment. These authors warn that practices such as stock distribution, rapid promotion, pension plans, among others, may be working against organizations by merely building instrumental bonds. As such, although these practices might encourage employees to continue in an organization, they do not necessarily motivate people to contribute or exercise extra effort on its behalf. In addition, individuals may wish to leave an organization but don't because of potential financial or social status loss. Affective commitment, despite being more difficult to promote, fosters strong bonds between people and organizational values, making them eager to contribute to organizational success.

Thus, in order to properly manage commitments, it becomes important to pay attention to the nature of the bond being strengthened. Companies can adopt practices aimed at achieving higher commitment levels, but the results obtained may produce unwanted effects (McElroy, 2001a) such as strengthening a continuance bond rather than an affective one. Meyer, Paunonen, Gellatly, Goffin, and Jackson (1989) produced empirical evidence that organizational affective commitment positively enhances performance, while continuance commitment has a negative influence on it. Cooper-Hakim and Viswesvaran (2005) also demonstrated consistent evidence of such influence in their metaanalysis.

In that regard, Bastos, Medeiros et al. (2008) proposed that it would be more appropriate to treat this instrumental relationship - continuance commitment - as a separate and different construct, which they called organizational entrenchment. It represents an extension of the construct proposed by 
Carson, Carson and Bedeian (1995) dealing with career commitment. This proposition is associated with a new research agenda in the area that calls for a deeper knowledge about the antecedents and consequences of organizational commitment and entrenchment.

Following a cognitive behavioral approach, this study works with the assumption that HRM practices produce results derived from perceptions and meanings people assign to them. Under this assumption, it focuses on analyzing the possible influences employees' perceptions have about the organization they work for on the linkages they develop with them. In doing so, it addresses the challenge posed by Medeiros, Galvão, Siqueira, and Marques (2002, p. 12) that "an evaluation of human resource systems, formed by a broad set of policies and practices of companies that produce commitment must also be made by the research of this field". According to Whitener (2001), a wellestablished stream of research rooted in social exchange theory has already shown that employees' commitment to an organization derives from their perceptions of the employers' commitment to, and support of, them. This in turn comes from their perceptions of organizational actions, such as HRM practices. Therefore this paper aims to identify HRM practices influences on organizational commitment and entrenchment by analyzing how they are perceived and what they signify to workers, contributing to better delimit these two constructs.

\section{Organizational Commitment and Entrenchment}

Commitment is a linkage that individuals may develop towards multiple aspects of their work environment. It can be enacted either as an attitude, behaviors (or behavioral intentions), or as a binding force. Commitment can be analyzed in relation to a wide range of foci - the organization, group or team work, work itself, career, and unions, among others. Therefore it can be thought of as a set of commitments where each one has some dimensions as well as antecedents, correlates, and consequents which can be unique or shared between these commitments (Mathieu \& Zajac, 1990; Meyer \& Herscovitch, 2001). Thus, factors that affect one dimension of commitment may impact other dimensions (Meyer, Allen, \& Smith, 1993; Morrow, 1993).

The organizational commitment concept derives from studies that explored the linkages that emerge between employees and organizations. The reason for these studies was the belief that committed employees have greater potential for improved performance, reduced absenteeism and turnover (Mowday, 1998). Organizational commitment was characterized in Mowday, Porter and Steers (1982) by three factors: a strong belief and acceptance of organizational goals and values; the wiliness to exert effort on behalf of it; and a strong desire to retain organizational membership. According to these authors, this goes beyond the passive concept of loyalty resulting in an active relationship aimed at the welfare of the organization.

For Meyer and others (Meyer \& Allen, 1991; Meyer et al., 1993; Meyer \& Herscovitch, 2001), commitment is a psychological connection that comes from three different bases: affective, normative and continuance. This concept is respectively based on the work of Mowday et al. (1982), Wiener (1982) and Becker (1960). It received empirical support from several other researchers (Dunham, Grube, \& Castañeda, 1994; Hackett, Bycio, \& Hausdorf, 1994; Hackett, Lapierre, \& Hausdorf, 2001). Affective commitment refers to the identification and involvement between the individual and a focus. Normative commitment reflects a feeling of moral obligation in relation to the focus. Continuance commitment (or instrumental) refers to an assessment of the implications (or price to pay) if the relationship with the focus is broken.

Due to its complexity, the work commitment construct has struggled with conceptual redundancy (Morrow, 1993). This occurs when concepts are not precisely defined to be mutually exclusive or when the link between a conceptual definition and measurement instrument (construct validity) is not perfect. Mowday (1998) states that there is an overlap between different models proposed for conceptualizing commitment. He points out that affective and continuance commitment, 
respectively, as proposed by Meyer and Allen (1991), overlap with internalization and compliance as proposed by O'Reilly and Chatman (1986). Morrow (1993) and Dunham, Grube, and Castañeda (1994), stated that the commitment defined by Mowday et al. (1982), is basically defined the same as affective commitment by Meyer and Allen (1991).

In sight of this diversity of interpretations and models, which results in lack of an agreed definition and consequent fragmentation of the construct, Meyer and Herscovitch (2001) proposed a model that represented an attempt to integrate them, generalizing the original work by Meyer and Allen (1991). This model attests to the existence of a core essence of the construct defined by linkages between the three categories affective, normative and continuance, and has been representing the mainstream of the commitment research since then.

However, despite representing a breakthrough, this model is not accepted by consensus in the field, mainly because of the overlap between the affective and normative commitment. Meyer and Allen (1991, p. 79) state that "the feelings of wanting to do and feel compelled to do may not be fully independent". According to Solinger, Ollfen, and Roe (2008), the three-dimensional model of commitment proposed by Meyer and Allen (1991) and Meyer and Herscovitch (2001), has its characterization of commitment strongly based on its role as a predictor of permanence, especially in relation to commitment arising from a continuance dimension. The affective basis, however, is considered by the authors as being more appropriate to the construct as it related to other consequents as well. Thus, the authors advocate a single dimensional affective view of the construct since the normative dimension is considered overlapped with it.

Moreover, empirical evidences have shown that continuance commitment produces effects contrary to affective commitment in relation to important consequents such as attendance and performance (Cooper-Hakim \& Viewesvaran, 2005; Meyer, Paunonen, Gellatly, Goffin, \& Jackson, 1989; Riketta, 2002; Steel \& Lounsbury, 2009). If this is the case, how can we call this linkage commitment if it produces a dissonant effect? Currently there are several authors focusing on commitment (Bastos, Rodrigues et al., 2008; Rodrigues, 2009; Solinger, Ollfen, \& Roe, 2008) who argue for more clarity and consistency since the construct now has possibly antagonistic dimensions, bearing different consequents. In this regard, a new concept called entrenchment was proposed and there is indication that it is indeed different than commitment (Carson, Carson, \& Bedeian, 1995; Rodrigues, 2009; Rodrigues \& Bastos, no prelo).

According to Bastos, Rodrigues et al. (2008), Rodrigues (2009), and Rodrigues and Bastos (no prelo), the entrenchment concept is more appropriate for predicting permanence in the organization than the continuance commitment. It was first defined by Carson et al. (1995) for the career focus and extended by those authors to the organizational focus. Entrenchment is a metaphor based on Becker's (1960) side-bets theory about staying in an organization or career when this is not really desired by the workers, but rather because it seems more secure. This cognition occurs when individuals do not adapt, are not motivated, or cannot find viable job alternatives to consider. So, they cannot leave their trench where they feel protected. This trench can be the organization they work for or their profession in general.

Carson et al. (1995) identified three dimensions of entrenchment: (a) loss of investment (time / money); (b) emotional costs; (c) lack of job alternatives. Bastos, Rodrigues et al. (2008) and Rodrigues (2009) proposed and developed a scale to measure entrenchment using slightly different dimensions, namely: (a) social position adjustments, which refers to the individual investments in the conditions necessary for adaptation and good performance in the organization; (b) impersonal bureaucratic arrangements, which refer to stability and financial gains to be lost if the individual left the organization; (c) limitation of alternatives, which concerns the perception of job opportunities available in the market for the worker. This scale was later validated by Rodrigues and Bastos (no prelo).

Therefore, entrenchment pertains to the option of continuing in the same line of action for lack of options, the sense of loss of investment already made, or the perception of an emotional price to pay 
too high to accept (Carson et al., 1995). Commitment, on the other hand, is related to consistency of line of action and rejection of alternatives (Kiesler, 1971). Symptoms of entrenchment may include: the desire to avoid social stigma, fear that age would make it hard to find a suitable job option, lack of desire to leave privileges already acquired, fear of losing something due to change. This would bring about a mindset of better being safe than sorry, as the popular saying goes, freezing people in their current work conditions (Carson et al., 1995).

According to Rodrigues (2009), the term entrenchment was given by Mowday et al. (1982) to the third and final phase of commitment development. These authors did not clarify the origin of the term they proposed. According to them, the entrenched individual would remain committed to the organization. However, the nature of this relationship can evolve and become more transactional. Entrenchment was therefore defined by them as a continuation of commitment bringing an echo to the term continuance commitment (defined by Meyer \& Allen, 1991) as they both refer to the worker's staying in the employing organization, when it does not stem from a desire but from need. Rodrigues (2009) states that the two concepts overlap and they can produce similar effects on the behavior of individuals. The author says: "Entrenched individuals are stuck in their careers (or organization) by necessity. So, one can assume that they are not very concerned with productivity, and not engaged into contributing, through their work to future generations" (p. 63).

Empirical evidence brought by Scheible, Bastos and Rodrigues (2007) supports this line of thinking. They carried out a survey among 217 workers in an Information Technology company in Brazil and analyzed the relationship of these two linkages - entrenchment and continuance commitment to the career - with performance and obtained relevant negative correlations in both cases.

\section{HRM Practices}

The history of HRM in organizations clearly shows how such practices are connected to the social, political, economic and technological context. The late twentieth century was marked by the technology boom and the increasing complexity and size of organizations, which became transnational. These new arrangements, apart from changes due to the pressures for more flexible production models that would accommodate non-standard products, eventually resulted in work routines "that become more dependent on the skills and knowledge at all levels of the production process" (Souza \& Peixoto, no prelo, p. 5), enhancing the importance of the human factor to organizations.

To cope with the dynamics of today's world and achieve a greater commitment from their employees, organizations changed their internal environment and ways of conducting the work through initiatives like position enrichment, encouragement of semi-autonomous or self-managed groups, minimizing the centralized authority and control of previous models. These more flexible forms of production organization combined with the restructuring that occurred in the 1980s (like downsizing and reengineering) that, in most cases, implied staff reduction, required new organizational structures and urged the need to overcome work management models based on stability and employee loyalty (Tonelli, Lacombe, \& Caldas, 2002). These new business models placed new demands on human resources management, as displayed in Table 1. 
Table 1

\section{Dimensions and Contemporary HRM Practices}

\begin{tabular}{ll}
\hline Dimension & Practice \\
\hline Work Relations & Conflict Regulation, Labor Relations, Management Model, Work Organization \\
People Management & $\begin{array}{l}\text { Analysis of Labor, Recruitment \& Selection, Career Planning, Movement of } \\
\text { Personnel, Benefits and Compensation. }\end{array}$ \\
Qualification \& Development & Training, Performance Evaluation, Career Development, Team Management. \\
Organizational Behavior & $\begin{array}{l}\text { Performance and Productivity, Leadership, Motivation, Satisfaction, } \\
\text { Commitment, Organizational Culture }\end{array}$ \\
Working Conditions and & $\begin{array}{l}\text { Safety, Accident Prevention, Ergonomics, Occupational Health, Stress } \\
\text { Hygiene }\end{array}$ \\
Organizational Change & Organizational Development, Quality of Life at Work, Total Quality \\
\hline
\end{tabular}

Note. Source: Adapted from Zanelli, J., \& Bastos, A. (2004). Inserção profissional do psicólogo em organizações e no trabalho (pp. 478-479). In J. C. Zanelli, J. E. Borges-Andrade, \& A. V. B. Bastos (Orgs.), Psicologia, organizações e trabalho no Brasil (pp. 466-491). Porto Alegre: Artmed.

This environment of change is consequently demanding new policies and management practices that are specifically aimed at retaining people, because they become increasingly trained to work in an environment of uncertainty and technological sophistication. Unstable environments demand more action and cooperation from the workforce, which calls into question the relative values of work, remuneration, leisure, personal life and organizational citizenship (Tonelli et al., 2002).

According to Grant (2003), when individuals perceive the tasks they are given is appropriate to their skill level, interests and knowledge, and believe that their work is recognized, they tend to value the organization's contributions to these factors and strengthen linkages with it, such as commitment and entrenchment. Bastos, Rodrigues, Moscon, Edington and Pinho (no prelo), argue that commitment is seen as a factor that enhances organizations' chances to successfully address turbulence and transitions. The meta-analytical work of Riketta (2002) and Cooper-Hakim and Viswesvaran (2005), respectively, demonstrate the positive relationships between organizational commitment and performance and retention.

So it seems possible to think of a core set of HRM practices which, combined, would influence employee ties to an organization, with commitment among them. Morrow (2011), however, states that although organizations practices are positioned to achieve high levels of talent retention and employee performance, little attention has been given to the role of affective commitment when establishing their HRM practices. This lack of attention seems to extend to the academic community as well, since some researchers produce self-criticism over the low level of attention being given to the importance of HRM practices as a factor for fostering commitment (Meyer \& Smith, 2000; Morrow, 2011).

According to Bastos et al. (no prelo), a committed workforce should be bound to an articulated set of practices that strengthen the ties of workers to the organization. Guest (1992) points out some challenges in this regards: (a) individuals' acceptance of such practices; (b) possible union interference in their implementation; and (c) each manager's individual interpretation of these practices, which can alter their original objectives. McElroy (2001b) highlights the importance of HR practices to fostering commitment. However, this author emphasizes the importance of considering the multiplicity of ties that individuals establish with the organization, because sometimes these links can be antagonistic.

Meyer and Herscovitch (2001) warn that this strategy should be adopted judiciously since these practices should aim on fostering affective commitment, but might end up impacting other linkages. Ideally, according to the researchers, practices should obtain greater affective commitment with minimal impact on other types of linkages. Pfeffer (1998) points out that HRM can produce one of the few forms of competitive advantage that is not easily imitated. McElroy (2001b) indicates the use of 
the practices defined by that author, listed in Table 2 , as a way to prioritize the people to foster commitment in organizations, identifying their likely impact on the types of commitment.

Table 2

HR Practices Impact on Organizational Commitment

\begin{tabular}{lccc}
\hline HRM Practice & Affective Commit. & Normative Commit. & Continuance Commit. \\
\hline Employment Security & + & + & + \\
Selection process & + & + & 0 \\
Decentralization/ Self management & + & + & + \\
Awards & + & 0 & + \\
Training & + & + & $0 /+$ \\
Social status difference reduction & $+/-$ & $+/-$ & $+/-$ \\
Information Sharing & + & + & 0 \\
\hline
\end{tabular}

Note. Source: McElroy, J. (2001b). Work commitment conceptual and methodological developments for the management of human resources. Human Resource Management Review, 11(1), 177-180.

Positive effect (+); Negative effect (-); No effect (0); Or ( / ).

According to McElroy (2001b), employment security refers to job stability as approached in this study but not in the sense commonly used in Brazil regarding governmental jobs. It refers to HRM practices intended to ensure that employees remain in the organization; for example, internal reassignments, etc. Security (or stability) in employment should produce positive effects on three types of commitment since the organizational values might become more institutionalized, investments grow as time passes, and the sense of security might entail reciprocity. Personnel selection may contribute to the affective and normative commitments to the organization. By selecting the best available candidates and building pride in the one chosen, an organization stimulates them to keep their promises.

Organizational structure decentralization and self-management tend to positively contribute to the three types of commitment. These promote and give visibility to participation in decision making, reinforcing these commitments. Concerning continuance commitment, this participation may represent a loss in the event of leaving the organization. Awards and recognition linked to organizational performance promote both affective commitment and continuance. The first fosters a feeling of being valued and the second a sense of perceived advantage. In both cases, the individual is expected to engage in behaviors that seek to improve organizational performance (McElroy, 2001b; Morrow, 2011).

McElroy (2001b) adds that training should enhance affective and normative commitments because they improve an individual's perception of self-importance. Regarding continuance commitment, the author defends that this will only be happen if a connection with new skills acquisition is clearly established. Meyer and Allen (1997) say that training is one of the best strategies that can be used to develop commitment because it facilitates the process of affiliation with the organization as well as making organizational support to the worker concrete. Regarding the reduction of status differences, McElroy (2001b) suggests that it can bring different results depending on the perspective of analysis. For those who lost status, it should be negative. On the other hand for lower ranks, it should be positive. Therefore its results are unpredictable.

Finally, Pfeffer (1998) states that information exchange can have a positive effect on affective and normative commitment as the organization uses information to influence and steer desired attitudes. However, such information must be corroborated by the socially constructed perceptions of individuals in their routine work, otherwise they would fall into discredit. Thus, when combined, 
according to Pfeffer (1998) and McElroy (2001b), these previously cited practices can leverage higher levels of commitment for the organization.

Locke and Latham (1984) cited by Grant (2003) indicate commitment as an essential prerequisite for effective task performance. These authors assert that in order to foster commitment to a goal, the following is necessary: (a) explain the purpose so it is perceived as something with value; (b) provide support to people who will work towards the goal; (c) encourage the participation of all; (d) provide adequate training to ensure people will to perform; (e) employ adequate selection processes; (f) and distribute incentive awards. In other words, they prescribe deployment of HRM practices directed to supporting and encouraging people, fostering their commitment, as advocated by Pfeffer (1998), McElroy (2001a, 2001b) and Grant (2003).

Scheible and Bastos (2006) analyzed commitments to organizational goals and project objectives and also concluded that HRM practices may contribute to their success. According to Mowday et al. (1982), and McElroy (2001b), commitment develops from individuals' expectations of and experiences with organizational practices and entrenchment its last phase. However, Meyer and Smith (2000) found no significant relationship between practices and continuance commitment. Based on these authors, a model was designed which is illustrated in Figure 1. The hypotheses outlined are the following: (H1) Perceptions of HRM practices are a determining factor (antecedent) of affective commitment to an organization; (H2) Perceptions of HRM practices are not a determining factor (antecedent) of organizational entrenchment.

Perceptions of HRM practices were collected via two dimensions: one direct and one comparative. This approach is more complete by considering not only the perception of practices from a direct and intra-organizational perspective, but also from a comparison with similar organizations (in other words - extra-organizational). For example, one can see that someone who works in an organization perceives that it offers opportunities for growth in a direct perspective. That perception can be refined by concluding if this is done to a greater or lesser extent when comparing with other organizations. The greater the perceived comparative advantage, the greater the tendency to strengthen commitment and entrenchment to the organization where he/she works for will be. So, showing this dimension separately should contribute to a better understanding of the relationship between perceptions of HRM practices and the linkages studied.

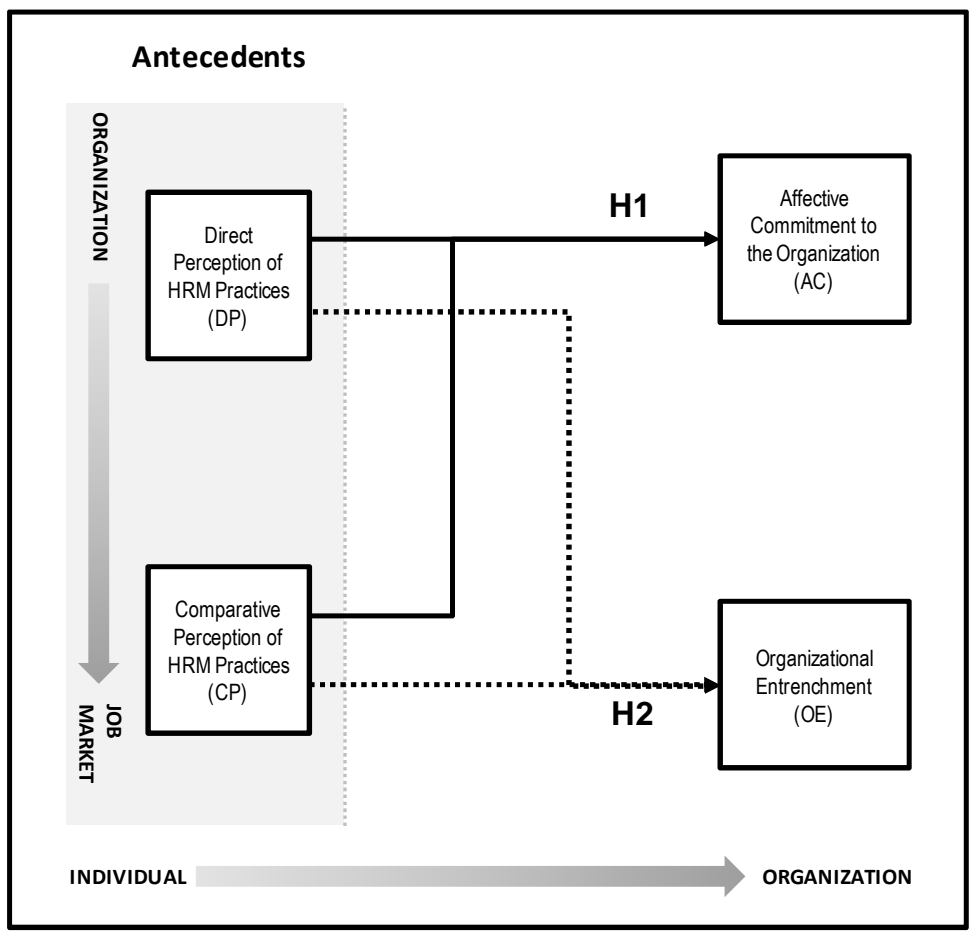

Figure 1. Hypothesis' Model. 


\section{Method}

After a comprehensive literature review, it was possible to establish a theoretical framework and outline a model with organizational commitment and entrenchment as dependent variables of perceptions of HRM practices. To achieve the objective of this study, a questionnaire was applied containing instruments to measure the variables chosen based on the literature review conducted. After collecting and processing the data, the hypothesized model was tested and conclusions were drawn based on the results obtained through the procedures applied. The survey was conducted in a nationwide Information Technology company, chosen due to its accessibility, especially in regard to people in different locations.

The company granted access to a group of about 1200 people. The survey was answered by people from several Brazilian states, totaling 307 respondents, which represents over $25 \%$ of the group. The questionnaire was applied electronically over the Internet. This procedure facilitated the collection process and increased participation for all business units and employees located in customers' sites. Another reason for this tactic was that the lengthy questionnaire required goodwill on the part of respondents. The questionnaire was available from July to September 2009. It consisted of three parts: demographic and functional items, items of scales to measure organizational affective commitment and entrenchment, and items relating to perceptions of HRM practices.

The scale proposed by Bastos, Medeiros et al. (2008), was used to measure organizational affective commitment to the organization. The reason behind this choice lies in the fact that it represents an attempt to find a scale with a better adjustment to the Brazilian context. In addition it limits the definition of commitment to the affective dimension as prescribed by Solinger et al. (2008). This scale incorporates items from the Organizational Commitment Questionnaire (OCQ) that are exempt from evocations of staying in the organization as well as items from the Affective Commitment Scale (ACS) from Meyer, Allen and Smith (1993), and also the scale proposed by Rego (2003), achieving higher reliability levels than the original scales ( 8 items, eigenvalue $=10.085, \alpha=$ 0.88) (Bastos, Medeiros et al., 2008).

To gauge organizational entrenchment, we used the scale proposed by Rodrigues (2009) and Bastos, Rodrigues et al. (2008). This scale represents a proposal for redefinition of the organizational commitment construct, separating the continuance dimension into a different construct called entrenchment. As defined by the aforementioned authors, this scale has 22 items divided into three dimensions. Bastos, Rodrigues et al. (2008, p. 1) reports the following results regarding the tests of each dimension: "(1) adjustment to social position ( 8 items, eigenvalue $=7.60, \alpha=0.80),(2)$ limitation of alternatives ( 7 items, eigenvalue $=1.93, \alpha=0.80)$, (3) impersonal bureaucratic arrangements ( 7 items, eigenvalue $=1.56, \alpha=0.77)$ ".

Taking as basis the McElroy's work (2001b) - see Table 2 - as well as Zanelli and Bastos (2004) - see Table 1, the following types of HRM practices were elected for the collection of perceptions: (a) Training and Development, (b) Benefits and Compensation, and (d) Stability. For each type two indicators were generated: the first referring to direct perception and the second comparing the practices of the organization studied with what is practiced in similar companies. We also generated a totalized indicator of perception for each of them by separately considering the two dimensions for each type of practice. They were calculated by averaging items in each practice from the direct and comparative perspectives, generating six variables, three for each type of perception. The final indicator for each perception was obtained by averaging these three indicators for each dimension. This procedure was used to give equal weight to each type of practice in both dimensions. The indicators for practice were calculated by the average of the direct and comparative items that related to each practice.

Exploratory factor analysis was applied to the HRM Practices Perceptions scale to verify its fit; applying the recommendations of Fabrigar, Wegener, MacCallum, Strahan (1999) in regard to extraction and rotation methods. A similar approach was used in Fiorito, Bozeman, Young, and Meurs 
(2007). The KMO (Kaiser-Meyer-Olkin) measure obtained was 0.884 , deeming the sample as adequate (meritory) for such a procedure. The three dimensions (one for each set of practices) were confirmed as depicted below (Table 3).

Table 3

Factor Analysis - Perceptions of HRM Practices

\begin{tabular}{lccc}
\hline Item & Training \& Develop. & $\begin{array}{c}\text { Benefits \& } \\
\text { Compensation }\end{array}$ & Stability \\
\hline Training to boost performance & .638 & .398 & .346 \\
Skills enhancement & .741 & .393 & .389 \\
Training preps future & .409 & .214 & .307 \\
Fair promotion system & .624 & .564 & .555 \\
Career Opportunities & .764 & .539 & .526 \\
Retention practices & .481 & .604 & .998 \\
Adeq comp x qualif & .484 & .779 & .506 \\
Adeq comp x colleagues & .375 & .550 & .317 \\
Opportunities to learn & .794 & .484 & .349 \\
Better retention practices & .496 & .630 & .836 \\
Better promo system & .456 & .885 & .577 \\
Better compensation & .381 & .806 & .508 \\
Better benefits & .287 & .369 & .276 \\
More opport to learn & .794 & .375 & .302 \\
Offers different tasks & .715 & .414 & .392 \\
\hline
\end{tabular}

Note. Extraction Method: Maximum Likelihood; Rotation Method: Promax with Kaiser Normalization.

All questions answered on the scale received a value of one to six on a Likert scale. The central neutral item was not used. Data were processed and analyzed for the presence of incomplete questionnaires (missing values) as well as to identify and remove outliers. Negative scale items were reversed.

The scales' internal consistency was examined and their reliability checked by calculating the Cronbach Alpha coefficient for each dimension. This ratio compares the overall change of scale with the variance of individual items. The normality of the sample for all variables was tested through the Kolmogorov-Smirnov test. It was possible to observe the non-normality for some of the perceptions assessed when analyzed by type of practice. However, the main variables were normally distributed. Thus, Pearson's correlation analysis was applied to determine the relationship between variables. Linear regression analysis with the Stepwise method was used to test the hypothesized relationship influences.

\section{Results and Discussion}

The analysis of personal characteristics on the data collected reveals the predominance of males (68\%), youth ( $22 \%$ below 25 years old and $34 \%$ between 26 and 30 years), unmarried (61\%) and with no dependents (73\%). The educational level is high (63\% with a college degree and $19 \%$ with 
incomplete university education). Most participants (45\%) work in Salvador, 15\% in Sao Paulo, and the remainder in other locations. Distribution by tenure is balanced, with $58.63 \%$ of employees having up to two years tenure in the organization. Individuals who do not exercise executive functions $(85 \%)$ are predominant in the sample collected.

The affective commitment average was higher than the entrenchment's. The bureaucratic arrangements dimension showed the highest average, but also presented the greatest variation. Perceptions of the HRM practices (direct or comparative) displayed middle levels, considering a scale of six. Table 4 below shows that training and development is the most appreciated type of HRM practice in the organization, since it has the highest average with the lowest standard deviation.

Table 4

\section{Descriptive Statistics}

\begin{tabular}{lccccc}
\hline Variable & N & Minimun & Maximun & Average & Std. Dev. \\
\hline Affective Organizational Commitment & 307 & 1.00 & 6.00 & 4.18 & .88 \\
Organizational Entrenchment & 307 & 1.00 & 4.47 & 2.50 & .69 \\
Entrench - Bureaucratic Arrangements & 307 & 1.00 & 5.80 & 3.00 & .98 \\
Entrench - Social Position Adjustments & 307 & 1.00 & 5.00 & 2.44 & .86 \\
Entrench - Lack of Alternatives & 307 & 1.00 & 4.43 & 2.17 & .81 \\
Direct Perception of HRM Practices & 258 & 1.00 & 5.67 & 3.36 & .98 \\
Comparative Perception of HRM & 307 & 1.00 & 6.00 & 3.60 & .88 \\
Practices & & & & & \\
Perception of HRM practice by type & & & & & \\
Training \& Developement & 258 & 1.00 & 5.90 & 3.86 & .96 \\
Compensation \& Benefits & 308 & 1.00 & 5.83 & 3.35 & .99 \\
Job Stability & 307 & 1.00 & 6.00 & 3.29 & 1.19 \\
\hline
\end{tabular}

All scales applied demonstrated at least good reliability levels as shown in Table 5. The highest confidence index was obtained for the organizational affective commitment scale proposed by Bastos, Medeiros et al. (2008). This index was 0.88 in the original work.

Table 5

Scale Reliability

\begin{tabular}{lcccc}
\hline \multicolumn{1}{c}{ Scale } & $\begin{array}{c}\text { Alpha } \\
\text { Cronbach }\end{array}$ & N & Reliability & Qty Items \\
\hline Affective Organizational Commitment & .904 & 306 & Excelent & 10 \\
Organizational Entrenchment & .864 & 307 & Very Good & 17 \\
Direct Perception of HRM Practices & .835 & 258 & Very Good & 08 \\
Comparative Perception of HRM Practices & .813 & 306 & Very Good & 07 \\
Perception of HRM practice by type & & & & \\
Training \& Developement & .856 & 258 & Very Good & 07 \\
Compensation \& Benefits & .804 & 308 & Very Good & 05 \\
Job Stability & .763 & 307 & Good & 03 \\
\hline
\end{tabular}




\section{Relationships between Perceptions of HRM Practices, Commitment and Entrenchment}

Relationships between the variables studied were initially identified. The results obtained are presented in Table 6. Affective commitment correlates strongly and positively with perceptions of HRM practices. Entrenchment is also positively related with the studied perceptions, but in a weaker magnitude than commitment. So, it can be said that individuals respond positively to the practices studied, since the better their perception about them, the greater their organizational linkage commitment or entrenchment. It seems natural to think that individuals develop linkages to the organization according to their perceptions of the practices that shape their professional context. However, when examining the relationship by type of practice, it was found that the practices of training and development do not relate to organizational entrenchment. These practices are more related to organizational values and indicate the promotion of conditions for the development of the individual and his/her career in the organization (or in the market). It is noteworthy that this type of practice showed the strongest correlation with affective commitment.

Table 6

Correlations between Commitment, Entrenchment and Perceptions of HRM Practices

\begin{tabular}{lcc}
\hline$(\mathrm{n}=307)$ & Commitment & Entrenchment \\
By dimension & & \\
Direct Perception of HRM Practices & $.518(* *)$ & $.143(*)$ \\
Comparative Perception of HRM Practices & $.575(* *)$ & $.192(* *)$ \\
By practice type & & \\
Training \& Developement & $.583(* *)$ & .076 \\
Compensation \& Benefits & $.397(* *)$ & $.238(* *)$ \\
Job Stability & $.465(* *)$ & $.138(* *)$ \\
\hline
\end{tabular}

Note. ${ }^{* *} \mathrm{Sig}=$ Correlation relevant at 0.01 level; $* \mathrm{Sig}=$ Correlation relevant at 0.05 level.

In order to generate more empirical knowledge about organizational entrenchment, the relationships between the entrenchments dimensions and perceptions of HRM practices were analyzed. The results presented in Table 7 show that the relationship entrenchment has with such practices is given by the two dimensions bureaucratic arrangements, which refers to financial gains and losses, and social position adjustments. The relationship between Compensation and Benefits practices and Bureaucratic Arrangements was the strongest found. This finding is consistent with the warnings given by McElroy (2001b) and Sethi and King (1998) about the care that should be taken with certain practices in order to avoid unwanted effects.

Table 7

Correlations between Entrenchment Dimensions and Perceptions of HRM Practices

\begin{tabular}{lccc}
\hline $\mathbf{n = 3 0 7})$ & Lack Alternatives & $\begin{array}{c}\text { Bureaucratic } \\
\text { Arrangemts. }\end{array}$ & Social Position Adj. \\
\hline Direct Perception of HRM Practices & .012 & $.190(* *)$ & $.158(*)$ \\
Comparative Perception of HRM Practices & .044 & $.198(* *)$ & $.241(* *)$ \\
By practice type & & & $.198(* *)$ \\
Training \& Developement & -.060 & .074 & $.182(* *)$ \\
Compensation \& Benefits & .055 & $.349(* *)$ & $.167(* *)$ \\
Job Stability & .095 & $.185(* *)$ & \\
\hline
\end{tabular}

Note. $* *$ Sig $=$ Correlation relevant at 0.01 level; * Sig= Correlation relevant at 0.05 level. 
The social position adjustments dimension consists of investments for adaptation and good performance in the organization and presented a significant relationship with perception of practices. The same applies to bureaucratic arrangements, except when related to HRM practices that address training and development. The perceptions of HRM practices did not correlate with the lack of alternatives dimension. This finding deserves more investigation in future studies because, as stated Rodrigues (2009), the limitation of job alternatives maintains a vicious circle with the other two dimensions. That is, although one cannot characterize it with an antecedent or consequent of entrenchment, it might be a separate construct that correlates with them.

The correlations between perceptions by practice type were also analyzed. Consistent with the prospect of a HRM practices system, positive and highly significant correlations were found between the practices focused on in this study. Job stability showed a correlation with training \& development of .598 and with compensation \& benefits of .602 . The latter also presented a .521 correlation with training $\&$ development. This implies that these practices do not operate in isolation; i.e., there are links between the practices for job stability, training and development (training, career opportunities, promotions), and compensation and benefits. So, when the perception of a practice changes, there is a tendency to change the perception of others. Furthermore, the correlation between direct and comparative perspectives attests to overlap, as it was .0794.

The test of the hypothesized model showed that perception of the HRM practices is indeed an antecedent of the two linkages studied as illustrated in Figure 2. From the relationships found, it is possible to infer that both commitment and entrenchment are influenced by the perception individuals have about HRM practices. This relationship is more strongly linked to affective commitment than to entrenchment. Thus, Hypothesis 1 is confirmed.

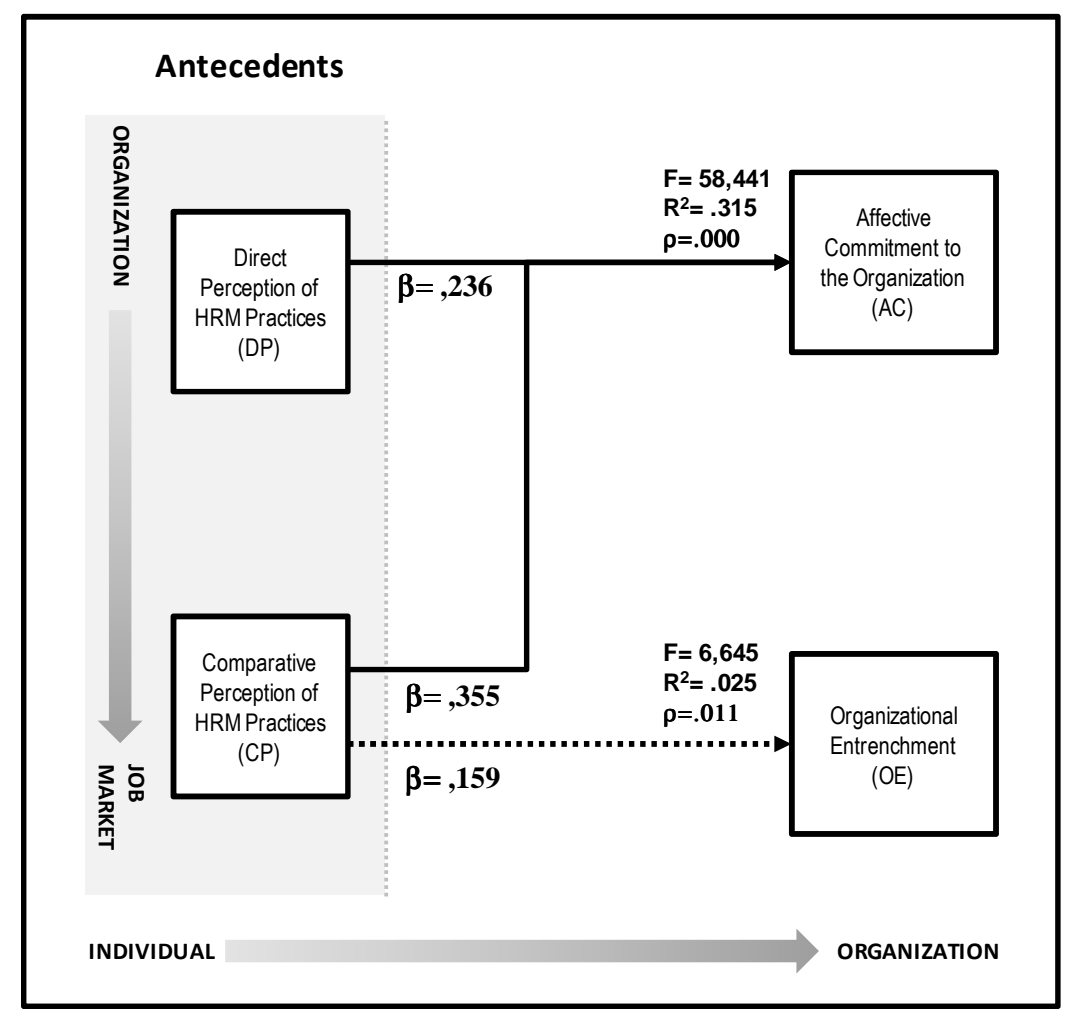

Figure 2. Tested Model.

Hypothesis 2, however, was not proven, even though at a very low level $\left(r^{2}=0.025, \beta=.159\right)$, perceptions of HRM practices were also found as antecedent of entrenchment. It can be argued that this result is not relevant enough to negate hypothesis 2 . However, one cannot disregard such evidence. Thus, further studies are needed to investigate this relationship. After all, this result, even at a low-level, confirms the warnings several authors have made about how some HRM practices have 
unwanted effects, such as strengthening other types of unwanted bonds (Guest, 1992; McElroy, 2001b; Meyer \& Herscovitch, 2001; Morrow, 2011; Sethi \& King, 1998).

The analysis of perception dimensions about HRM practices reveals that the comparative perspective has a stronger influence on linkages than the direct one. The direct perception showed no influence over entrenchment. This finding leads to the conclusion that the analysis individuals do to check the balance of what they receive from the organization (e.g., salary and benefits) compared to what they give to it (e.g., time and skills) to perceive the advantage of remaining in the organization and the potential losses they would suffer by leaving, described as the basis for continuance commitment according to Whitener and Walz (1993), is carried out in a comparative fashion.

In order to further investigate, we performed analysis of what types of practices contribute more strongly to commitment and entrenchment, as illustrated in Figure 3.

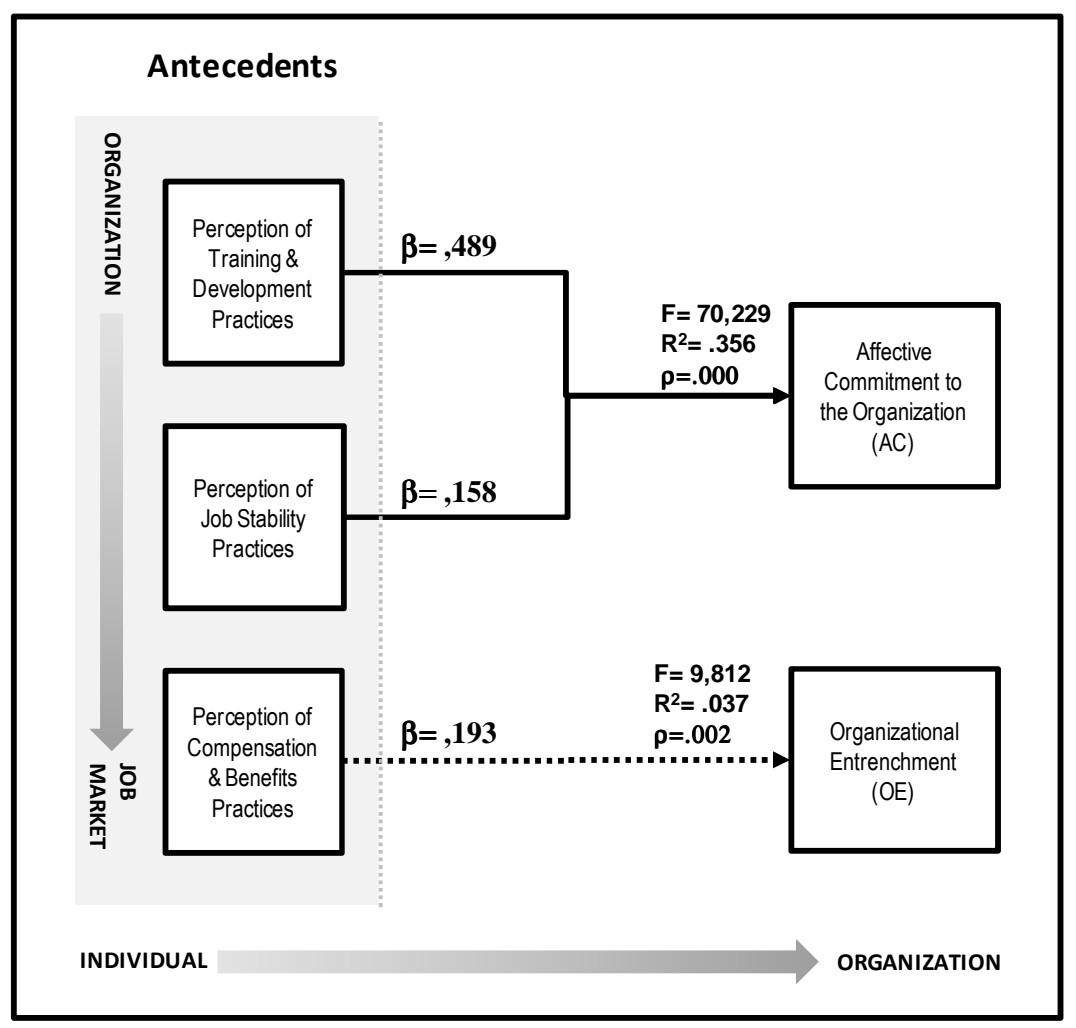

Figure 3. Model by HRM Practice Type.

Training and Development and Stability represent the kind of practice that fits better in the results desired by managers for HRM practices. They strongly influence commitment without enhancing entrenchment. The relationship between training and commitment has been amply documented in commitment literature, following the example of Meyer et al. (1991, 2001), who asserted that commitment, both affective and normative, is positively related to training. According to Fiorito et al. (2007), practical training implies career opportunities. Thus, based on human capital theory, employees perceive investment in their training as symbols of continuity in their jobs and in higher compensation. So they value training initiatives for the implicit safety and future improvements, and this makes them more committed.

On the other hand, Compensation and Benefits practices only affected entrenchment on a small scale. That is, the perception of higher wages and more benefits increases an individual's perception of the losses that would have to leave the organization, while it does not contribute to the improvement of their alignment with organizational objectives and values. While the strength of this result is not overwhelming, it is consistent with the theory of side-bets proposed by Becker (1960), which 
underlies the concept of entrenchment. Therefore, although the result was not statistically significant, the hypothesis was not validated because it is consistent with the theoretical background. This result suggests that while organizations must possess competitive compensation schemes, affective commitment is not obtained in an instrumental way, as suggested by Sethi and King (1998), even though Fiorito et al. (2007), argue that compensation \& benefits practices may affect both affective and continuance linkages. For these authors, although benefits have instrumental value for employees, these benefits also indicate that the organization values them. However, in their study this type of practices did not help to increase organizational commitment.

\section{Concluding Remarks}

During the last decades, numerous studies have been done with the aim of identifying and clarifying the linkages that connect individuals and organizations. These studies are justified in considering these linkages as predictors of behaviors relevant to the organizational context, such as absenteeism, turnover, and performance, as well as the need to identify the foundations of behavior patterns desired by organizations (Cohen, 2003). Previous research has concluded that HRM practices may play an important role in the development of such linkages even though their implementation should be carefully carried out in order to avoid undesired outcomes. According to the authors, commitment can become a competitive advantage, if properly managed (McElroy, 2001b; Pfeffer, 1998).

According to Meyer and Allen (1997) and Arthur (1994), the most important thing is to understand and implement a complete set of practices, or a system of HRM practices, and not think of them as isolated practices. Arthur (1994) adds that an HRM system is strategic to organizations. Consistent with this approach, the present study does not address the perception of individual practices but of subsets. The perceptions were captured from two perspectives - direct and comparative - in order to better ascertain their influence over the linkages studied. Meyer and Smith (2000) found no relationship between HRM practice and continuance commitment. Would they have found a different result if a comparative approach was used as well? This is an investigation to be carried out in other studies as Morrow (2011) also reported striking results with only training as an antecedent of commitment. The results found in this paper also point out Training \& Development practices as the most predominant type of practice for fostering commitment.

Arthur (1994) differentiates practices aimed at controlling from those geared to foster organizational commitment. The former are intended to reduce workforce size and increase efficiency, forcing workers to obey rules and procedures, and using rewards based on measurable products. Practices oriented on organizational commitment seek to model attitudes and behaviors that strengthen the psychological bond between workers and organizational objectives. Training and Development practices are included in this set, as the results $\left(r^{2}=0.356, \beta=.489\right)$ found here prove they are antecedents of affective commitment to an organization.

The findings reported delineate relationships between HRM practices and linkages with the organization, reaching this paper's objective of identifying such. Practices aimed at symbolic exchanges, which concern preparation and growth of individuals, recognition, and affiliation with the organization are practices that have a strong positive influence on affective commitment in the organization studied. Practices of a more instrumental nature showed a very weak influence over entrenchment. Thus organizations should invest in HRM practices, as they constitute factors that strengthen linkages between a company and its employees.

Despite the interesting findings, several limitations should be considered. This paper focused on a set of practices that could be expanded, and samples of organizations with different professional profiles should be analyzed, since the present study is restricted to a limited set of practices and to a particular line of business. Future studies should further investigate the relationship between 
entrenchment and Compensation \& Benefits practices. Moreover, the relationship between these practices and the Lack of Alternatives dimension should also be subject to other studies. Another limitation refers to the profile of the respondents who have a high level of education and practically belong to a single professional category. Thus, the ability to generalize is limited. The results may be influenced by nonresponse bias and volunteer bias, especially since the data collection was done through the internet. In addition, the present study (similar to most of the research in this area) was based on single methods. Future research should collect data from multiple sources through multiple methods, including structured interviews, company records, and observation. Even with these limitations, this study contributes to the knowledge of how to manage people within organizations, identifying practices that help make them committed and entrenched, shedding some light onto the question of whether commitment can be managed.

\section{References}

Arthur, J. (1994). Effects of human resource systems on manufacturing performance and turnover. Academy of Management Journal, 37(3), 670-687. doi: 10.2307/256705

Barros, A. (2007). Comprometimento organizacional: um estudo de suas relações com práticas de gestão de pessoas e intenção de permanência (Dissertação de mestrado). Universidade Federal da Bahia, Salvador, Brazil.

Bastos, A., Medeiros, C., Brito, A., Rodrigues, A., Aguiar, C., \& Lisboa, C. (2008, October). Organizational Commitment: enhancing the measure of the affective, continuance, and normative bases for the Brazilian work context. Anais da Conferência Internacional de Avaliação Psicológica: Formas e Contextos, Braga, Portugal, 13.

Bastos, A., Rodrigues, A., Aguiar, C., Silva, E., Barreiros, B., \& Lisboa, C. (2008). Organizational Entrenchment: a scale proposal and its factorial validation on Brazilian workers. Anais da Conferência Internacional de Avaliação Psicológica: Formas e Contextos, Braga, Portugal, 13.

Bastos, A., Rodrigues, A., Moscon, D., Edington, E., \& Pinho, A. (no prelo). Comprometimento no trabalho: fundamentos para a gestão de pessoas. Manuscrito submetido à publicação.

Becker, H. (1960). Notes on the concept of commitment. American Journal of Sociology, 66(1), 32-40. doi: $10.1086 / 222820$

Carson, K. D., \& Bedeian, A. G. (1994). Career commitment: construction of a measure and examination of its psychometric properties. Journal of Vocational Behavior, 44(3), 237-262. doi: $10.1006 /$ jvbe. 1994.1017

Carson, K. D., Carson, P., \& Bedeian, A. (1995). Development and construct validation of a career entrenchment measure. Journal of Occupational and Organizational Psychology, 68(4), 301320. doi: 10.1111/j.2044-8325.1995.tb00589.x

Cohen, A. (2003). Multiple commitments in the workplace. Mahwah, New Jersey: Lawrence Erlbaum Ass. Pub.

Cooper-Hakim, A., \& Viswesvaran, C. (2005). The construct of work commitment: testing and integrative framework. Psychological Bulletin, 131(2), 241-259. doi: 10.1037/00332909.131.2.241

Dunham, R., Grube, J. A., \& Castañeda, M. B. (1994). Organizational commitment: the utility of an integrative definition. Journal of Applied Psychology, 79(3), 370-380. doi: 10.1037/00219010.79.3.370 
Fabrigar, L. R., Wegener, D. T., MacCallum, R. C., \& Strahan, E. J. (1999). Evaluating the use of exploratory factor analysis in psychological research. Psychological Methods, 4(3), 272-299. doi: 10.1037//1082-989X.4.3.272

Fiorito, J., Bozeman, D., Young, A., \& Meurs, J. (2007). Organizational commitment, human resource practices, and organizational characteristics. Journal of Managerial Issues, 19(2), 186-207.

Grant, A. (2003). Having yourself committed: bridging between personal projects and organizational commitment (Unpublished report/2003). Cambridge, MA, United States, Harvard University.

Guest, D. (1992). Employee commitment and control. In J. Hartley \& G. Stephenson (Eds.), Employment relations (pp.111-135). Oxford: Blackwell.

Hackett, R. D., Bycio, P., \& Hausdorf, P. A. (1994). Further assessment of Meyer \& Allen's threecomponent model of organizational commitment. Journal Applied Psychology, 79(1), 15-23. doi: 10.1037/0021-9010.79.1.15

Hackett, R. D., Lapierre, L. M., \& Hausdorf, P. A. (2001). Understanding the links between work commitment constructs. Journal of Vocation Behavior, 58(3), 392-413. doi: $10.1006 /$ jvbe. 2000.1776

Kiesler, C. (1971). The psychology of commitment: experiments linking behavior to belief. Londres: Academic Press.

Mathieu, J. E., \& Zajac, D. M. (1990). A review and meta-analysis of the antecedents, correlates, and consequences of organizational commitment. Psychological Bulletin, 108(2), 171-194. doi: 10.1037//0033-2909.108.2.171

McElroy, J. (2001a). Managing workplace commitment by putting people first. Human Resource Management Review, 11(1), 327-335.

McElroy, J. (2001b). Work commitment conceptual and methodological developments for the management of human resources. Human Resource Management Review, 11(1), 177-180.

Medeiros, C., Galvão, L., Siqueira, M., \& Marques, G. (2002, setembro) Comprometimento organizacional: o estado da arte da pesquisa no Brasil. Anais do Encontro Nacional da Associação Nacional de Pós-Graduação e Pesquisa em Administração, Curitiba, PR, Brasil, 28.

Meyer, J., Paunonen, S., Gellatly, I., Goffin, R., \& Jackson, D. (1989). Organizational commitment and job performance: it's the nature of the commitment that counts. Journal of Applied Psychology, 74(1), 152-156.

Meyer, J. P., Allen, N. J., \& Smith, C. A. (1993). Commitment to organizations and occupations: extension and test of a three-component conceptualization. Journal of Applied Psychology, 78(4), 538-551. doi: 10.1037//0021-9010.78.4.538

Meyer, J. P., Allen, N. J., \& Topolnytsky, L. (1998). Commitment in a changing world of work. Canadian Psychology, 39(1), 83-93. doi: 10.1037/h0086797

Meyer, J. P., \& Allen, N. J. (1991). A three component conceptualization of organizational commitment. Human Resource Management Review, 1(1), 61-89. doi: 10.1016/10534822(91)90011-Z

Meyer, J. P., \& Allen, N. J. (1997). Commitment in the workplace: theory, research, and application. Thousand Oaks, CA: Sage.

Meyer, J. P., \& Herscovitch, L. (2001). Commitment in the workplace: toward a general model. Human Resource Management Review, 11(3), 299-326. doi: 10.1016/S1053-4822(00)00053-X 
Meyer, J. P., \& Smith, C. A. (2000). HRM practices and organizational commitment: test of a mediation model. Canadian Journal of Administrative Sciences, 17(4), 319-331. doi: 10.1111/j.1936-4490.2000.tb00231.x

Morrow, P. (1993). The theory and measurement of work commitment. Greenwich: JAI Press.

Morrow, P. C. (2011). Managing organizational commitment: insights from longitudinal research. Journal of Vocational Behavior, 79(1), 18-35. doi: 10.1016/j.jvb.2010.12.008

Mowday, R. T. (1998). Reflection on the study and relevance of organizational commitment. Human Resource Management Review, 8(4), 387-401. doi: 10.1016/S1053-4822(99)00006-6

Mowday, R. T., Porter, L. W., \& Steers, R. M. (1982). Employee-organization linkages: the psychology of commitment, absenteeism, and turnover. New York: Academic Press.

O'Reilly, C., \& Chatman, J. (1986). Organizational commitment and psychology attachment: the effects of compliance, identification, and internalization on prosocial behavior. Journal of Applied Psychology, 71(3), 492-499. doi: 10.1037/0021-9010.71.3.492

Pfeffer, J. (1998). The human equation: building profits by putting people first. Boston: Harvard Business School Press.

Rego, A. (2003). Comprometimento organizacional e ausência psicológica: afinal, quantas dimensões? Revista de Administração de Empresas, 43(4), 25-35. doi: 10.1590/S0034-75902003000400003

Riketta, M. (2002). Attitudinal organizational commitment and job performance: a meta-analysis. Journal of Organizational Behavior, 23(3), 257-266. doi: 10.1002/job.141

Rodrigues, A. C. A. de (2009). Do comprometimento de continuação ao entrincheiramento organizacional: o percurso de validação da escala e análise da sobreposição entre os construtos (Dissertação de mestrado). Universidade Federal da Bahia, Salvador, Brasil.

Rodrigues, A. C. A. de, \& Bastos, A. V. B. (no prelo). Entrincheiramento organizacional: construção e validação da medida. Psicologia: Reflexão e Crítica.

Scheible, A., \& Bastos, A. (2006, setembro). Comprometimento com a carreira: explorando o conceito de entrincheiramento. Anais do Encontro Nacional da Associação Nacional de Pós-Graduação e Pesquisa em Administração, Salvador, BA, Brasil, 30.

Scheible, A., Bastos, A., \& Rodrigues, A. (2007, setembro). Comprometimento e entrincheiramento: integrar ou reconstruir? Uma exploração das relações entre estes construtos à luz do desempenho. Anais do Encontro Nacional da Associação Nacional de Pós-Graduação e Pesquisa em Administração, Rio de Janeiro, RJ, Brasil, 31.

Sethi, V., \& King, R. (1998). The multidimensional nature of organizational commitment. Journal of Information Technology Management, 9(1), 13-26.

Solinger, O., Ollfen, W. van, \& Roe, R. (2008). Beyond the three-component model of organizational commitment. Journal of Applied Psychology, 93(1), 70-83.

Souza, J., \& Peixoto, A. (no prelo). Os novos modelos de gestão e os impactos na atuação do psicólogo organizacional. Manuscrito submetido à publicação.

Steel, R. P., \& Lounsbury, J. W. (2009). Turnover process models: review and synthesis of a conceptual literature. Human Resource Management Review, 19(4), 271-282. doi: 10.1016/j.hrmr.2009.04.002 
Tonelli, M., Lacombe, B., \& Caldas, M. (2002). Desenvolvimento histórico do RH no Brasil e no mundo. In G. Boog (Org.), Manual de gestão de pessoas e equipes: estratégias e tendências (pp. 59-84). São Paulo: Ed. Gente.

Whitener, E. M. (2001). Do "high commitment" human resource practices affect employee commitment? A cross-level analysis using hierarchical linear modeling. Journal of Management, 27(5), 515-535. doi: 10.1177/014920630102700502

Whitener, E. M., \& Walz, P. M. (1993). Exchange theory determinants of affective and continuance commitment and turnover. Journal of Vocational Behavior, 42(3), 265-281. doi: 10.1006/jvbe.1993.1019

Wiener, Y. (1982). Commitment in organizations: a normative view. Academy of Management Review, 7(3), 418-428. doi: 10.5465/AMR.1982.4285349

Zanelli, J., \& Bastos, A. (2004). Inserção profissional do psicólogo em organizações e no trabalho. In J. C. Zanelli, J. E. Borges-Andrade, \& A. V. B. Bastos (Orgs.), Psicologia, organizações e trabalho no Brasil (pp. 466-491). Porto Alegre: Artmed. 